\title{
Health Social Policy in Facing the New Paradigm of Industrial Revolution 4.0
}

Kebijakan Sosial Kesehatan Menghadapi Paradigma Baru Revolusi Industri 4.0

\author{
Endro Tri Susdarwono \\ email: saniscara9gmidas@gmail.com \\ Universitas Peradaban Bumiayu
}

\begin{abstract}
Health is not a health un sick, since it is contextual, as society defines health differently, at least by four aspects: cultural pattern, the cultural standard of health changes over time, technology affecting people's health, social inequality affecting people's health. Poor and wealthy countries have their specific health issues. In poor countries, health problems are mostly famine, malaria, cholera/diaries, skin disease, and infection. Health problems are mostly caused by a bad environment, dirty water, and bad sanitation. Health problems in rich countries, especially in the US, are mostly heart attack stroke, and obesity. There are two approaches to health social policy: the prevention and the cure. Prevention is sometimes called the social well-being policy to increase people's health conditions. Another understanding of prevention is social work, which has a broader meaning that social life does not only refer to health. While the cure is commonly understood as a "social health care system", as noted by Johnson and Schwartz defined as a system generally responsible for sickness and disability. Why government shall develop health policy, create a mechanism for health care, and manage health prevention ?". The first answer is that a healthy society is an assurance for national productivity, and therefore competitiveness. The second answer is that a healthy society generates additional disposable income. There is no single best way to develop health policy. There are many rooms and spaces to develop creative health policy.
\end{abstract}

Keywords: health, health social policy, healthy society, national productivity.

Abstrak: Kesehatan bukanlah kesehatan yang tidak sakit, karena itu bersifat kontekstual, sebagaimana masyarakat mendefinisikan kesehatan secara berbeda, setidaknya melalui empat aspek: pola budaya, standar budaya kesehatan yang berubah dari waktu ke waktu, teknologi mempengaruhi kesehatan masyarakat, ketimpangan sosial yang mempengaruhi kesehatan masyarakat. Negara miskin dan kaya memiliki masalah kesehatan khusus mereka sendiri. Di negara-negara miskin, masalah kesehatan paling banyak terjadi pada kelaparan, malaria, kolera / buku harian, penyakit kulit dan infeksi. Masalah kesehatan sebagian besar disebabkan oleh lingkungan yang buruk, air kotor dan sanitasi yang buruk. Masalah kesehatan di negara kaya, terutama di AS, kebanyakan adalah serangan jantung, stroke, dan obesitas. Ada dua pendekatan kebijakan sosial kesehatan: pencegahan dan pengobatan. Pencegahan terkadang disebut sebagai kebijakan kesejahteraan sosial yang bertujuan untuk meningkatkan kondisi kesehatan masyarakat. Pengertian lain dari pencegahan adalah pekerjaan sosial, yang memiliki arti lebih luas bahwa kehidupan sosial tidak hanya mengacu pada kesehatan. Sementara penyembuhan umumnya dipahami sebagai "sistem perawatan kesehatan sosial", sebagaimana dicatat oleh Johnson dan Schwartz didefinisikan sebagai sistem yang secara umum bertanggung jawab atas penyakit dan kecacatan. Mengapa pemerintah harus 
SOEPRA Jurnal Hukum Kesehatan

TERAKREDITASI RISTEKDIKTI Peringkat 4

ISSN:2548-818X (media online) Vol. 6 (2) Desember 2020

mengembangkan kebijakan kesehatan, membuat mekanisme perawatan kesehatan, dan mengelola pencegahan kesehatan? ". Jawaban pertama, masyarakat yang sehat merupakan jaminan bagi produktivitas nasional, dan oleh karena itu berdaya saing. Jawaban kedua adalah bahwa masyarakat yang sehat menghasilkan pendapatan tambahan. Tidak ada satu cara terbaik untuk mengembangkan kebijakan kesehatan. Ada banyak ruang dan ruang untuk mengembangkan kebijakan kesehatan kreatif.

Kata kunci: kesehatan, kebijakan sosial kesehatan, masyarakat sehat, produktivitas nasional.

\section{INTRODUCTION}

One of the serious weaknesses of public health experts is their ability to understand the development policy process of an area including health policy. That is one of the scopes of health politics. It is not surprising that health problems are always seen wrongly by development leaders, both at the center and in the regions. ${ }^{1}$

What public health experts think is very different from what political leaders think in seeing development. Public health experts always see health as the main and the only way to achieve prosperity, maternal and child health is a priority, rich and poor inequality is the source of health problems, health policy and politics must be evidence-based and prevention approaches are the main ones. Unfortunately, political leaders, who are the leaders of a region, do not look the same in seeing health development issues. They are more focused on how to increase popularity for the interests of re-elected, look good in front of the media, middle and upper economic classes get more attention by continuing to echo the defense of the poor, political decisions are based more on the results of a survey of political popularity and development priorities more to the looks fast in the eyes of constituents.

At the root of the problem of this sharp difference is that public health experts are reluctant to understand the political problems of development and especially health development. The hope is that one day the sharp differences between public health experts and development politicians will diminish and converge towards health development that benefits health development goals so that the health degree rises well. The degree of public health is influenced by four main factors, namely: the environment, behavior, health services, and heredity. Therefore efforts to maintain and improve community health status must be aimed at the four main factors together.

Government, private sector, and non-governmental organizations have provided or built environmental health facilities in the community, such as family toilets, toilets (washing and toilet facilities), clean water facilities, etc., but are not or not utilized or maintained by the Public. Likewise, health facilities, such as puskesmas, hospitals, posyandu, etc. have been built everywhere, but their use by the community is still low. This is because people's behavior is not ready to accept it all, aside from the fact that the facilities are not in accordance with the values or habits of the community.

Health Law No. 36 of 2009 provides limitations: health is a healthy condition physically, mentally, spiritually, and socially that allows everyone to live productively socially and

${ }^{1}$ Sukri Palutturi, 2010, Kesehatan itu Politik, Semarang: Karya Aksara, hal i. 
economically. The limitation that is lifted from the health limit according to the most recent World Health Organization (WHO) is indeed broader and dynamic compared to the previous limit which says, that health is a perfect state, both physical, mental, and social, and not only free from disease and defective. In the previous limitation, health only covered three aspects, namely: physical, mental, and social, but according to Law No. 23/1992, perfected by Law No. 36 of 2009, then health includes five aspects, namely physical (body), mental (soul), social, spiritual, and economic. ${ }^{2}$

This means that a person's health is not only measured from the physical, mental, spiritual, and social aspects but also measured from the probability in terms of having a job or producing economically. For those who have not entered working age, children, and adolescents; or for those who are not working (pension) or "usila" (old age). Be productive socially, i.e. to have activities, for example, school or college for children and adolescents, and social service activities for "usila" (the elderly). The five dimensions of health influence each other in realizing the level of health in a person, group, or community. That is why health is holistic or comprehensive. The form or indicator of each of these aspects of individual health is as follows : 3

1. Physical health is manifested when a person does not feel sick and is clinically not sick. All organs of the body are normal and functioning normally or there is no impairment of bodily functions.

2. Mental health (soul) includes two components, namely: mind and emotions.

a. A healthy mind is reflected in a person's way of thinking, which is able to think logically (reasonable) or think coherently.

b. Healthy emotions are reflected in a person's ability to express their emotions, such as fear, joy, worry, sadness, and so on.

3. Spiritual health is reflected in the way a person expresses gratitude, praise, or worship of the creator of nature and everything (Allah, Almighty). Easily, healthy spirituality can be seen from religious practices or beliefs, as well as good deeds in accordance with the norms of society.

4. Social health is manifested when a person is able to relate to other people well or is able to interact with other people or groups without discrimination of race, ethnicity, religion or beliefs, social status, economy, politics, and so on; mutual respect and tolerance.

5. Health and economic aspects can be seen from the productivity of a person (adult) in the sense of having activities that produce something that can support his life or his family financially. For children, adolescents, and the elderly themselves, this limit does not apply. For them, productive here means having activities that are useful for their lives later, such as school or college for students, and service or religious activities for "Iusila" (the elderly).

This study discusses how health social policy is the facing of a new paradigm of the industrial revolution 4.0. In the industrial revolution, the corporation will not be productive and competitive if half of their workers are ill. National competitiveness which was generated by national productivity is supported by people's health.

\footnotetext{
2 Soekidjo Notoatmodjo, 2012, Promosi Kesehatan dan Perilaku Kesehatan, Jakarta: Rineka Clpta, hal 1. 3 lbid, hal 1-2.
} 


\section{RESEARCH METHODS}

This research includes normative legal research that only uses secondary data. The type of legal research is a comprehensive analytical study of primary and secondary legal materials. The results of the study are presented in full, detailed, clear, and systematic as scientific work. The method used is a normative juridical approach. Because this research is normative legal research, the approach uses an analytical normative approach, by following the steps as follows:

1) identify the legal sources that form the basis of the problem formulation;

2) identify the main topics and subtopics which originate from the formulation of the problem;

3) identify and inventory normative provisions of primary and secondary legal materials based on detailed sub-topics;

4) examine comprehensively analytical primary and secondary legal materials in order to answer the problems that have been formulated;

5) the results of the study as an answer to the problem are described in full, detailed, clear, and systematic in the form of research reports or scientific papers.

The research specification in this research uses analytical descriptive, which describes the results of the research in accordance with the problems and objectives to be achieved and analyzes them in terms of applicable laws and regulations.

In this study using the determination of the sample by means of non-probability sampling or non-random sampling by sampling using purposive sampling adjusted to the purpose of the study. The sample size is not a problem. Samples were taken only in accordance with the objectives of the study. In other words, the sample contacted is a sample that matches certain criteria determined based on the research objectives. Data collection methods use literature study (bibliography study), documents (document study), and archive studies (file or record study).

Data analysis (analyzing), which describes data in the form of sentences that are good and right, so that it is easy to read and be given meaning (interpreted) so that the results of data analysis make it easier to draw conclusions inductively. The legal material (data) results of the processing are analyzed qualitatively and then discussed. Based on the results of the discussion then conclusions are drawn as answers to the problems studied.

\section{RESULTS AND DISCUSSION}

What is health? health is a state of complete physical, mental, and social well-being. ${ }^{4}$ Let's see ourselves now. Do we feel healthy today? What do you think about people who live in the garbage areas, do they feel healthy? How about the homeless? Then, if you live in tropical countries, and you do a bath once a day, will you consider yourself is healthy enough?

Health is not a health un sick, since it is contextual, as society defines health differently, at least by four aspects :

4 John J. Macionis, 2008, Society: the Basics, Singapore : Pearson Education, hal 427. 
1. Cultural pattern, in which the standard of health varies from one culture to another culture. How people perceived health is the reflection of what is morally good, because health fits cultural mores.

2. Cultural standard of health changes over time. Fifty years ago, actors smoking a cigarette was called "macho". Today, smoking is generally accepted as a dangerous and deadly habit. According to Gallup, in the US in the year 2000, people are taking a bath every day, and it is three times more comparing to fifty years ago.

3. Technology affecting people's health. Malnutrition and infection disease seldom to become a concern of society in poor countries, such as in the Middle-Africa. It happened in Malaysia, Indonesia, and Singapore, about 50 years ago; but now, when development and industrialization have embraced those nations, health becomes their main concern. It is not only about wealth, but technology makes people aware of the condition to be called "unhealthy".

4. Social inequality affecting people's health. Societies distribute resources unequally. There is a global fact that the rich have far better physical, mental, and emotional health than the poor. ${ }^{5}$

There are two important things that must be recalled to lay the foundation and basic concepts of health development primarily related to human capital in Indonesia as part of countries that live in a globalized world.

First, the Declaration of Alma-Ata (the Declaration of Alma-Ata). This is the first international conference on primary health care that was held at Unisoviet on September 12, 1978. This conference also provided a strong foundation for the development of puskesmas in the country. The conference was attended by approximately 134 countries in the world unanimously declaring and agreeing to build a health sector throughout the world that we are often familiar with "Health for All years 2000 and beyond", which is healthy for all in 2000. Said beyond "the Health for All by the year 2000 and beyond", shows that the ideals to achieve health for all not only reach the 2000 limit, but they're clear that these goals and efforts must continue after 2000. Conference sponsored by the World Health Organization (WHO) ) and the World Organization that handles child issues (UNICEF) states unanimously the accuracy of which includes: ${ }^{6}$

First, this conference reaffirms that health is a healthy, physical, mental, and social condition that is not only free from disabilities and weaknesses. Human rights are the most basic ("... a state of complete physical, mental and social well-being, and not merely the absence of disease or infirmity is a fundamental human right ... "). This statement shows that the state is obliged to guarantee the health of its citizens without distinction of ethnicity, race, religion, socio-economic differences, rank, and position of each person.

Secondly, this conference also stated that not only did everyone have the right but also had the obligation to participate individually and in groups in the planning and implementation of health services (the people have the right and duty to participate individually and collectively in the planning and implementation of their health care). This shows that in fact the concept of community participation and bottom-up planning has been stated by countries in the world since 30 years ago. The community is a very important part to be involved in the planning and implementation of activities.

$5 \mathrm{lbid}$, hal 427-428.

${ }^{6}$ Palutturi, op.cit., hal 5-6. 
Assessment of community needs becomes very important to deal with health problems that actually occur, health problems that are felt by the community (perceived needs), public health problems that have been shown and done (expressed needs), health problems expressed by experts or that have been made in the form of guidelines (normative needs) and health problems expressed by comparing health problems in one region to another, health problems between one province and another, and so on (comparative needs). With a strong and truly needed assessment, it will produce a health program that is well-targeted both in terms of the program and economically in terms of the budget.

The second important point is the Ottawa Charter or called the Ottawa Charter. This is the first international conference on health promotion in Ottawa, Canada which was held on November 21, 1986, a conference that is no less important than the previous conference. Because this conference was held in Ottawa which resulted in an agreement charter then it became known as the Ottawa Charter or the Ottawa Charter. If the Alma-Ata declaration lays the foundation for achieving Health for All, the Ottawa Charter emphasizes the framework of action that can be taken to achieve Health for All. There are five components of action that are considered important for developing health promotion programs and programs. ${ }^{8}$

First, building a healthy public policy (building healthy public policy). Health policy has a different meaning from "healthy policy" (healthy policy). Health policy emphasizes policies relating to health, policies relating to healthy people to stay healthy and not get sick, and policies relating to sick people to heal, not be disabled and guarantee their health. Meanwhile, building a healthy policy means that healthy development policies must be placed on the top of the policymaking agenda. BJ Habibie called it a health-oriented development. This is very important to understand correctly because often this time it is understood that this task is the task of the health sector. ${ }^{9}$

Second, creating a supportive environment (creating a supportive environment). Our society is very complex and interconnected. Health cannot be separated from other goals. Changing patterns of life, work and leisure will give very significant meaning to health. Protecting nature and developing the environment and conservation of natural resources must be aimed at health promotion strategies. ${ }^{10}$

Third, strengthening community actions and actions (strengthening community action). The heart of the process of strengthening the community movement is community empowerment. The concept of community empowerment was apparently not a new issue, far earlier also countries in the world stated the importance of community empowerment both empowerment in terms of information and networks as well as empowerment in terms of resources. ${ }^{11}$

Fourth, is developing personal skills (developing personal skills). This becomes very important, in addition to the community being facilitated in the form of information, the community must also be encouraged to improve their education and skills. Developing

\footnotetext{
7 Ibid, hal 5-6.

8 Ibid, hal 7.

9 lbid,.

10 Ibid,.

${ }^{11}$ lbid,.
} 
strong personal skills in the community will make it easier to mobilize Human Resources. With their skills and education, the community can independently develop a program that will be carried out. ${ }^{12}$

Point penting terakhir dari Ottawa Charter ini adalah reorientasi pelayanan kesehatan (reorienting health servides). Intinya di sini adalah bahwa pelayanan kesehatan harus dilihat dari hulu ke hilir. Masalah kesehatn tidak akan mungkin selesai hanya dengan menunggu orang sakit datang ke Puskesmas, rumah sakit, dan dokter praktek. Masalah kesehatan tidak akan mungkin selesai hanya dengan memberikan Jaminan Kesehatan Masyarakat kepada penduduk Indonesia. Yang lebih penting adalah bahwa kebijakan kesehatan harus diarahkan dan diorientasikan pada orang sehat, agar mereka tetap sehat sambal menyelesaikan maslah kebijakan yang orientasinya pada orang sakit termasuk Jamkesmas itu sendiri.

The last important point of the Ottawa Charter is the reorienting of health services. The point here is that health services must be seen from upstream to downstream. Health problems will not be possible just by waiting for the sick to come to the health center, hospital, and doctor practice. Health problems will not be solved simply by providing Community Health Insurance to the population (Jamkesmas) of Indonesia. What is more important is that health policies must be directed and oriented towards healthy people, so that they stay healthy while solving policy problems that are oriented towards the sick including "Jamkesmas" itself.

In the western community, as mentioned by Butler and Calnan (1999), health policy faces six major challenges :

1. Controlling cost. The rising cost of healthcare is a challenge for the government at most because it has an impact on the other sectors of the national economy. This is applied in countries whose healthcare service is mostly financed by the private sector, like the US, and by the public sector, as in the UK (in the UK more than $80 \%$ of its healthcare is provided by the public sector). The spectacular development of medical technology still cannot solve the problems of increasing health expenditure. ${ }^{13}$

2. Balancing supply and demand. People's demand for health care is running not linear with the health systems require to satisfy people's demand. It tends to be inadequate. Therefore the approach of balancing can also be described as "rationing". ${ }^{14}$

3. Strengthening scientific-based healthcare. It is about improving the scientific basis of healthcare to ensure that the treatments received by patients are clinically effective and appropriate to their needs. The solution is commonly known as "evidence-based medicine" which means the quest for a stronger scientific basis to improve costeffectiveness. Therefore this approach is about the cost-benefit" and the "costeffectiveness" of health treatments. ${ }^{15}$

4. Health promotion and disease prevention. The doubt about the effectiveness, the benefits, and the cost of medical treatments coupled with the increasing importance of

\footnotetext{
$12 \mathrm{lbid}$, hal 8.

13 Butler, John, and Michael Calnan, 1999, "Health and Health Policy", in John Baldock, Nick Manning, Steward Miller and Sarah Vickerstaff, eds., 1999, Social Policy, New York : Oxford University Press, hal 326-327.

$14 \mathrm{lbid}$, hal 328-329.

$15 \mathrm{lbid}$, hal 330.
} 
behavioral and environmental factors as the cause of disease; government then change the health policy "to protect" rather than "to cure". ${ }^{16}$

5. The need to tackle inequalities. There are strong critics about inequalities in many healthcare services.

6. Developing appropriate organizational structures. The demand for the most efficient and effective healthcare system is based on two arguments: the conventional wisdom which perceived the involvement of government in the day-today public health services, and the market approach that the health services shall be provided by private as government duties has become "overload". ${ }^{7}$

Those six healthcare issues are also relevant in developing countries, as health becomes the critical factor of global social policy. Poverty has trapped people in severe health problems. In many parts of Africa, where people's life expectancy is barely fifty, most children die before reaching teenagers.

The Classical Theory developed by Blum (1974) says that there are four main determinants that affect the health status of individuals, groups, or communities. The four determinants are ordered based on the magnitude of the influence on health are: 1) the environment, both the physical environment and non-physical environment (social, cultural, economic, political, and so on); 2) behavior; 3) health services; and 4) hereditary or hereditary. These environmental determinants can be further divided into two groups, namely the physical environment (weather, climate, facilities, and infrastructure, etc.), and non-physical environments, such as the social, cultural, economic, political, and so on.

The degree of health in this sense is clearly distinguished between the degree of health of individuals, groups, or communities (communities). This can be understood because the health degrees of individuals (individuals), groups, and communities are different. Determinants for group or community health may be the same, but for individual health, in addition to these four factors, individual internal factors also play a role, for example, age, gender, education, etc., in addition to hereditary factors. Therefore, if we further analyze that health determinants are actually all factors outside of human life, both individually, groups, and communities that directly or indirectly affect human life. This means, in addition to the determinants of health status that have been formulated by Blum there are still other factors that influence or determine the realization of the health of a person, group, or community. ${ }^{18}$

If we observe in society, especially in developing countries like Indonesia, the three social problems that exist are a) ignorance - due to low education, b) various diseases - due to low degrees and health services, and c) poverty (poverty) - due to low economy. These three things influence each other and form a vicious circle:

a. Ignorance - poverty - sickness.

b. Poverty - disease (unable to maintain health) - ignorance.

c. Disease - poverty (not productive) - ignorance (unable to go to school).

\footnotetext{
$16 \mathrm{Ibid}$, hal 331-333.

17 Ibid, hal 337-338.

${ }^{18}$ Notoatmodjo, op.cit., hal 5 .
} 
Therefore a solution to break the chain can be done through the three joint efforts, the results of which will also influence each other:

a. Education: aims to combat ignorance, can affect the ability to improve work or work, so as to increase income (economy). Furthermore, it will be able to improve the ability to prevent disease, increase the ability to maintain and improve health.

b. Economy: aims to increase income per capita (economy to combat poverty, which can affect community access to higher education. Highly educated people can affect the ability to prevent disease, improve the ability to maintain and improve health.

c. Health: aims to fight the disease so that it can improve the level of health. A high degree of health can have an effect on increasing productivity. Furthermore, high productivity means the economy increases, and a high economic level will increase access to high education as well, which means ignorance also decreases.

Sociologists study health and disease not only because it is intrinsically attractive, and is a central issue of human existence - that is, sickness, suffering, and death - but also because the study helps us understand how society works. For sociologists, experiences of illness and illness are the result of community organizing. For example, poor living and working conditions cause people to get sick, and poor people will die faster, than people at the top of the social system. Even though there are improvements in living conditions and medical practices, class, gender, and ethnicity inequalities are not addressed, the gap between the rich and the poor remains sustainable. Sickness and inequality are intertwined. As a result of the unequal distribution of political, economic, and social resources needed for healthy living is a social element of health. People who are at the top of the social system are healthier and live longer, while those who are at the bottom of the social system are more vulnerable to illness and shorter lives, and more people die from diseases and accidents that can actually be prevented. ${ }^{19}$

In our daily lives, there are three dominant representations of disease causes, especially those found in the media (newspapers, medical documentary drama, and soap opera TV). The first is the genetic explanation. Genetic explorations regularly appear in articles and programs in which claims are built that there is a genetic cause for obesity (obesity), drug addiction, alcoholism, divorce, and homosexuality, to name a few that are commonly emerging. However, there is no evidence of genetic contribution to cultural practices, and also there is no scientific justification for negative moral evaluation in the realm of medical science. These conditions are culturally specific and professionally defined - not natural "facts". Furthermore, little can be done with genetic diseases. The lack of genetic planning experiments causes knowledge about the role of genetics does not help individuals or policymakers to deal with the disease. In fact, by reducing the explanation of individual conditions back to the lowest common denominator of biology, genetic explanation systematically ignores sociological explanations, and functions to divert our attention from the ways in which social life shapes our experiences of the disease. Between genetic predisposition to certain cases and their development lies in intervening variables, namely politics, economics, gender, and ethnicity. These variables must be considered when explaining the transformation of "genetic risk" towards social reality.

19 Kevin White, 2011, Pengantar Sosiologi Kesehatan dan Penyakit, Jakarta : Rajawali Pers, hal 1-2. 
The second general assumption is that ill experiences cause social mobility to decline, and conversely, healthy experiences increase social mobility. This is an extension of Darwin's socalled argument about the survival of the fittest. There is no support for this argument in the literature. The ones who suffer the most are, of course, the poorest in society, they are sick because they are poor, not vice versa they are poor because they are sick. When conditions of illness and deteriorating social mobility intersect, this is a condition in which political, cultural, and social practices have discriminated against individuals - mothers who are alone caring for children, people with disabilities, people of color, and people who have AIDS. ${ }^{20}$

The third dominant explanation of the existence of disease is that humans adopt a lifestyle that makes them sick, and for us, individuals are responsible for the conditions they face. Lifestyle explanations that claim that bad choices are freely determined, for example in terms of diet, smoking, and exercise make the sick. Again, there is very little evidence that individual efforts at this level will achieve much towards a healthier society. A good lifestyle choice will be influenced by broader structural variables in determining healthy and sick. Lifestyle behaviors are nothing more than a small portion of health status. Although it determines, because the behavior of life is structurally unequal compared to individual choices, then the behavior is more the result of inequity than the cause. ${ }^{21}$

For health sociologists, all three explanations contain similarities. All three believe that someone falls ill, then the condition of the disease is the problem of the person's body and their unique biology. In other words, the exploration of individualizing and biologizing the exploitation of the disease. Often times the explorations combine in explorations that blame individual choices for life that the doctor cannot overcome, because of the genetic mapping he has. Biological expansion of "excessive" individuals is very common in societies based on racial status groups. ${ }^{22}$

Sociological analysis, on the other hand, focuses on lifestyle as a political and economic formation that subordinates certain populations, an approach that explains that the continuation of systematically adapted aspects of the culture of the population is useful.

The sociological arguments for health are particularly important in the political and economic nature of the present day. There is a large restructuring process of the labor market in the Westernist economic economy, with the deterioration of industry and, in relation to labor unions, and class-based politics. There has been extensive intensive liberalism - that should actually be involved in the provision of welfare services, and that individuals should be more responsible for their own lives. Economic changes are sometimes shortened in the context of "postmodernity" - that is dependent on organized capitalism, and into a period where consumption is balanced rather than a key to social life. Some sociologists celebrate these changes. The claim is that life is increasingly living in a postmodern world, which is free from industrial capitalism structures and the old nuclear bourgeois family. For Ulrich Beck, this change means that human beings "will be burdened from the social forms of industrial society - class, coating, family, and gender status" (Beck, 1992: 87). Identity is liquid and negotiable, separated from "social structure", which claims to be a pigment in the imagination of sociology. For some theorists, the discovery of the

\footnotetext{
$20 \mathrm{lbid}$, hal 4.

${ }^{21} \mathrm{lbid}$, hal 4-5.

$22 \mathrm{lbid}$, hal 5.
} 
body, which intertwined with a weakened structure, reinforces the argument that we are constructing our bodies just as we think. Anthony Giddens, for example, emphasizes the openness of the body, and the openness of the individual to form it: "the responsibility for the design of one's own body" (Giddens, 1992: 102). In line with these requirements, Bauman (1992) argues that the knowledge of sociology and the world in which life is uncertain is ambivalent, irregular, and insecure. A stable base of identity has been lost, and so has social science knowledge certainty. At the core of this change, according to Bauman (1998), is the transformation of the culture of production, where labor, frugal and disciplined, changes into a hedonistic world that is free (hedonistic indulgence). Instead of working to produce savings for the future and social prestige, we are still rewarded with "free sex", drug trafficking, and "living on the road quickly".

Various perspectives of sociology regarding society develop various roles of medical knowledge and the role of social causes of disease. The sociology perspective is also based on various sociological models about society, both mutually supportive and conflicting. Following are the simpleness of Sociology of Health:

Table 1. the simpleness of Sociology of Health. ${ }^{23}$

\begin{tabular}{|c|c|c|c|}
\hline Theory & Models of Society & Causes Diseases & Role of Medical Practitioners \\
\hline Maxis & $\begin{array}{l}\text { Conflict and } \\
\text { Exploitation }\end{array}$ & Prioritize the benefits of health & $\begin{array}{l}\text { Discipline and control the } \\
\text { class of workers, and provide } \\
\text { individual explanations about } \\
\text { the disease }\end{array}$ \\
\hline Parsonian & $\begin{array}{l}\text { Basically, is a set of } \\
\text { harmonious and stable } \\
\text { relationships and social } \\
\text { structures }\end{array}$ & $\begin{array}{l}\text { Social tension (social strain) is } \\
\text { caused by meeting social } \\
\text { needs and roles. }\end{array}$ & $\begin{array}{l}\text { Individual rehabilitation to } \\
\text { carry out social roles. }\end{array}$ \\
\hline Foucauldian & $\begin{array}{l}\text { A network of } \\
\text { relationships, powers, } \\
\text { and resources - } \\
\text { oversight managed. }\end{array}$ & $\begin{array}{l}\text { "Disease" is the label used to } \\
\text { sort and differentiate the } \\
\text { population to be easily } \\
\text { controlled. }\end{array}$ & $\begin{array}{l}\text { Imposing adherence to } \\
\text { "normal" social roles, and to } \\
\text { ensure that we internalize } \\
\text { norms. }\end{array}$ \\
\hline Feminists & $\begin{array}{l}\text { Exploitative and } \\
\text { repressive towards } \\
\text { women through the } \\
\text { patriarchy }\end{array}$ & $\begin{array}{l}\text { Running the social role of } \\
\text { women as determined by men } \\
\text { (patriarchy); medical } \\
\text { treatment of women around } \\
\text { the life cycle of their } \\
\text { reproduction. }\end{array}$ & $\begin{array}{l}\text { Imposing conformity with } \\
\text { patriarchal norms about } \\
\text { femininity and motherhood. }\end{array}$ \\
\hline
\end{tabular}

Poor and wealthy countries have their own specific health issues. In poor countries, health problems are mostly famine, malaria, cholera/diaries, skin disease, and infection. Health problems are mostly caused by a bad environment, dirty water, and bad sanitation. Health problems in rich countries, especially in the US, are mostly heart attack stroke, and obesity.

But still, there are several common health problems in both areas: sexually transmitted disease - from gonorrhea to HIV/AIDS, cigarette effect"illness-lung-cancer, stroke, cancers, and new global disease which some of which remain unanswered, such as Ebola, bird flu, swine flu.

23 Ibid, hal 9. 


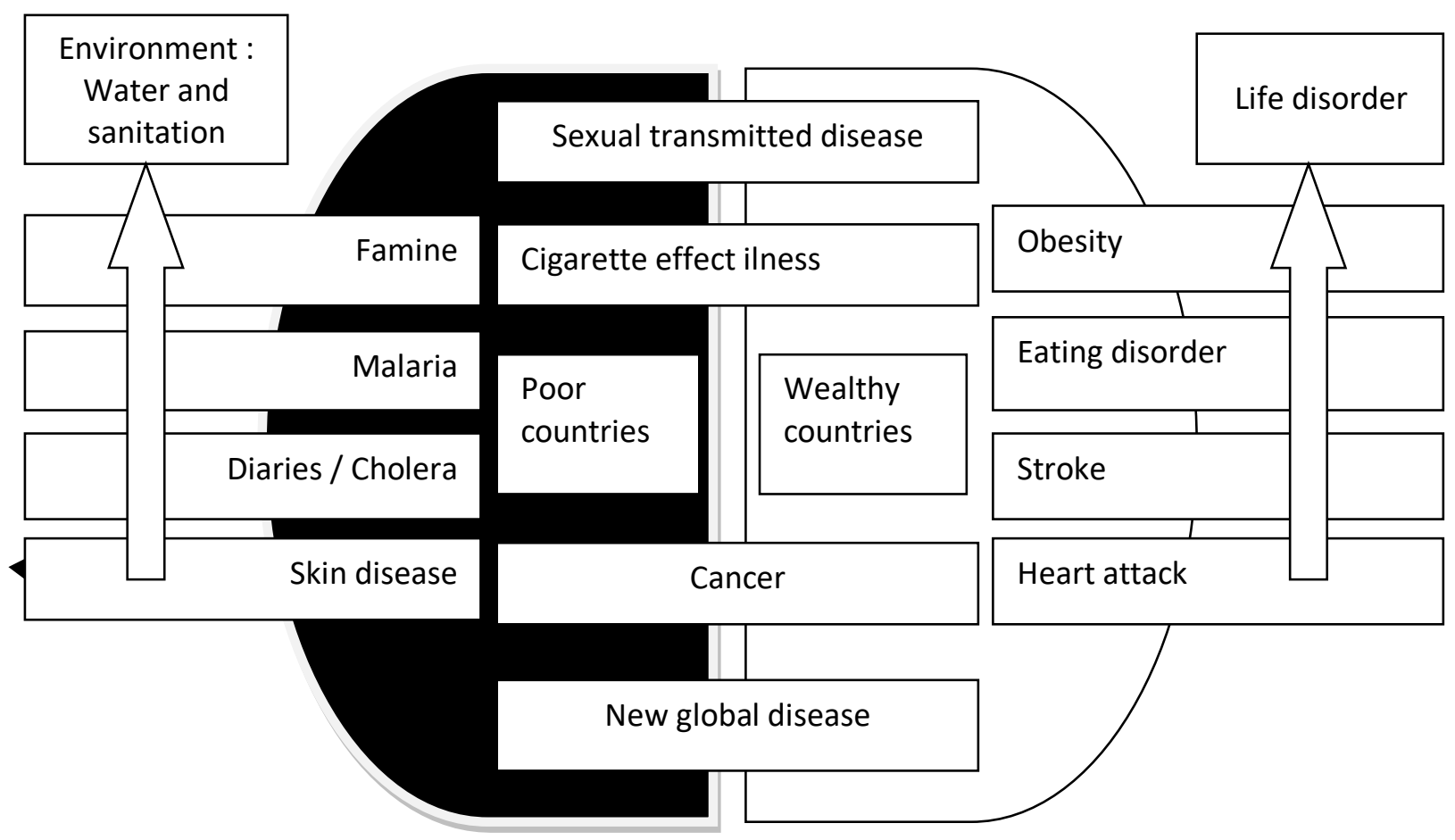

Figure 1. Common health problems in several poor and wealthy countries

There are two approaches to health social policy: the prevention and the cure. The prevention is sometimes called the social well-being policy with the objective to increase people's health condition. Another understanding of prevention is social work ${ }^{24}$, which has a broader meaning that social life does not only refer to health. While the cure is commonly understood as a "social health care system", as noted by Johnson and Schwartz defined as a system generally responsible for sickness and disability. ${ }^{25}$

The prevention approach of health social policy is exercised by three basic strategies, which are :

1. Healthcare insurance

2. Public health support

3. Outbreak prevention

The Healthcare insurance model is provided by two structures: universal health care insurance as a compulsory action for people and government. Otto von Bismarka from Germany was the first person who introduced the universal health insurance model for all of his citizens. In the US, there are two universal health care systems funded by the government: Medicaid, free medical support for the poor and the old people. In Indonesia, government released the universal health insurance financed by the government entitled

${ }^{24}$ Louise C Johnson and Charles L. Schwartz, 1994, Social Welfare : A Response to Human Need, Massachussets : A. Llyn\& Bacon, hal 205.

25 Ibid,. 
the "National Health Social Insurance System". Despite that, there is private health insurance, additional health insurance for upper-middle communities.

Public health support is an activity promoted by the government and implemented in the national community. In 1980, the number of child mortality in Indonesia was high. The government was then introduced the "Integrated Service Post", or to be known as Posyandu, a weekly health activity conducted in sub-villagers around the nations with two objectives: to assure the health of post-maternal mothers and children. The doctors are provided by the government, but the place and other supports are provided by the local community, i.e. table, chair, baby-scales, milk, and healthy food. The project is still going on until today, and worldly accepted as one of the best community-based health programs.

An outbreak prevention program is the health activity to promote the importance of public prevention against any suspected or potential outbreak. In Kuala Lumpur, activities to prevent dengue fever outbreak occur almost every day; as the authority execute mass spraying activities around public housings. In 2004, in order to prevent a bird flu outbreak, Jakarta Health offices performed a mass inspection of all chicken farming and traditional market and disinfected suspected areas.

The second strategy is delivering health care. In developed countries, health care is provided by public and private hospitals. Therefore, health care means "hospital". In developing countries, health care is also provided by society, to be called traditional health care, such as massage or native healing. In the Philippines, it is common for local people to seek medical alternatives. Sometimes, people choose to have traditional health service rather than modern medical treatment in regard to their traditional beliefs. In many parts of Indonesia, there are so many famous bone-massagers who re-experienced to cure people with bone-crack. The study of health care introduced by the western paradigm seldom recognizes this practice. Sometimes the traditional treat is more effective than modern medical treatment.

Basically, there are two healthcare approaches, which are the universal and selective approach. Based on Johnson and Schwartz, countries with universal provision of health care providers access to health care services for all people. The idea is challenged by two arguments, which are excessive cost and inferior quality of services ${ }^{26}$ proposed by the selective approach. The approach argued that the number of people eligible for health provision tends to increase, such as the poor and the elder. Health care services might collide with the demographic issue.

As solutions for the health care problem, there is health insurance. Rashi Fein, a medical economist at Harvard Medical School, identified three approaches to health insurance :

1. A private market approach promotes the idea that people get health care insurance from their employment. If public, the government would provide vouchers or tax credits for low-income people. However, it often creates excessive health care costs. It is a two-tier system and does not cover long-term care.

2. Employer-based approach, or often known to be "to play or to pay". Health insurance is available for everyone through employers or the government. Employers must provide health care insurance. Some proposals are including long-term and preventive care.

${ }^{26} \mathrm{lbid}$, hal 209. 
3. Government based approach. This plan is known to be a single-payer or national health insurance. The government is the sole payer where everyone receives guaranteed basic hospital and doctor coverage. Usually, preventive care is included and sometimes long-term care is also included. Various funding mechanisms are suggested. A major criticism of this approach is that it increases taxes considerably.

For developing countries; the preferred health insurance, as prior discussed, is in two tiers: universal and commercial. The most adaptive approach in regard to the financial issue is the Managed Health Care (MHC) Model, as developed by Kaiser Permanente US. By this approach, the insurance is neither reimbursed nor paid by the hospital, instead of managed by MHC. In Indonesia, the model is exercised by the National Health Company, a government-linked company, which manages health care prevention for civil servants and some labor-intensive industries in Indonesia.

\section{CONCLUSIONS}

the question is: "why government shall develop health policy, create a mechanism for health care, and manage health prevention ?". The first answer is that a healthy society is an assurance for national productivity, and therefore competitiveness. The second answer is that a healthy society generates additional disposable income. There is no single best way to develop health policy. There are many rooms and spaces to develop creative health policy.

\section{REFERENCES}

Butler, John, and Michael Calnan, 1999, "Health and Health Policy", in John Baldock, Nick Manning, Steward Miller, and Sarah Vickerstaff, eds., 1999, Social Policy, New York: Oxford University Press.

Johnson, Louise C., and Charles L. Schwartz, 1994, Social Welfare: A Response to Human Need, Massachusetts: A. Llyn \& Bacon.

Macionis, John J., 2008, Society: the Basics, Singapore: Pearson Education.

Notoatmodjo, Soekidjo, 2012, Promosi Kesehatan dan Perilaku Kesehatan, Jakarta : Rineka Clpta.

Palutturi, Sukri, 2010, Kesehatan itu Politik, Semarang : Karya Aksara.

White, Kevin, 2011, Pengantar Sosiologi Kesehatan dan Penyakit, Jakarta : Rajawali Pers. 